\title{
ANALISA FAKTOR - FAKTOR YANG MEMPENGARUHI MINAT MASYARAKAT BERINVESTASI DI PASAR MODAL SYARIAH MELALUI BURSA GALERI INVESTASI UISI
}

\author{
Ahmad Dahlan Malik \\ Program Studi Ekonomi Syariah, Fakultas Ekonomi dan Bisnis, Universitas Internasional Semen Indonesia \\ Email: ahmad.malik@uisi.ac.id atau ahmaddahlanmalik@gmail.com
}

\section{ARTICLE HISTORY}

Received:

07 June 2017

Accepted:

16 June 2017

Online available:

30 June 2017

Keywords:

Consideration of

investment, Risk, income, Motivation, Knowledge,Perception, Learning.

\section{ABSTRACT}

As an attempt to economic growth in the country aftermath of the financial crisis around the world economy, and in an attempt to support the policies implemented by the government, the need for investors to give their roles through the capital market is necessery. As the development of capital markets to reduce uncertainty and the role of capital markets in real terms, the Islamic capital market formed that aims to accommodate investors from both Muslims and non-Muslims. As an investor in the development efforts of its role in the Islamic capital market, analyzes the need for investors to be interested to invest their capital in the Islamic capital market. In these goals, this study was undertaken to analyze the factors factors that affect the interests of investors through the stock gallery UISI investment in the form of risk factors, income levels, motivation, knowledge, perception, and learning to invest in the Islamic capital market. The results of research conducted has a model $Y=0.011+0.386+0.380 \mathrm{X} 1+0.290 \mathrm{X} 2$ X3 - X4 0,016 - 0,045 X5 - X6 0.005. These models are becoming a significant role of the respondent or investor in BGIU (Exchange Gallery UISI Investment) through risk, income, and motivation variables which has important than others because the variables have positive regression. 


\begin{abstract}
ABSTRAK
Kata Kunci:

Pertimbangan

investasi, Risiko,

Pendapatan, Motivasi,

Pengetahuan,

Persepsi, Belajar

Sebagai upaya untuk pertumbuhan perekonomian negara setelah terjadinya finansial krisis di seluruh perekonomian dunia, dan sebagai upaya untuk menunjang kebijakan yang dilakukan oleh pemerintah, diperlukannya investor untuk memberikan perannya melalui pasar modal. Sebagai perkembangan pasar modal untuk mengurangi ketidak pastian dan peran pasar modal dalam segi riil, terbentuklah pasar modal syariah yang bertujuan untuk menampung investor baik dari Muslim maupun non muslim. Sebagai upaya perkembangan investor dalam perannya di pasar modal syariah, diperlukannya analisa untuk investor agar berminat untuk menanamkan modal mereka di pasar modal syariah. Dalam tujuannya tersebut, dilakukanlah penelitian ini dengan menganalisa faktor - faktor yang mempengaruhi minat investor melalui bursa galeri investasi UISI berupa faktor risiko, level pendapatan, motivasi, pengetahuan, persepsi, dan belajar dalam berinvestasi di pasar modal syariah. Dari hasil penelitian yang dilakukan menghasilkan model $\mathrm{Y}=0,011+0,386 \mathrm{X} 1+$ 0,380 X2 + 0,290 X3-0,016 X4-0,045 X5 - 0,005 X6. Dari model tersebut yang menjadi peran signifikan adalah dari variabel risiko, pendapatan dan motivasi yang penting untuk diperhatikan terhadap responden atau investor di BGIU (Bursa Galeri Investasi UISI) dibanding yang lain karena variabel tersebut berregresi positif.
\end{abstract}

\title{
PENDAHULUAN
}

Perkembangan ekonomi global berpengaruh terhadap perekonomian Indonesia. Setelah mengalami krisis yang cukup berat, perekonomian Amerika Serikat (AS) pada pertengahan tahun 2014 mulai membaik Perbaikan kinerja negara maju ditopang oleh kebijakan dalam memicu konsumsi dan investasi di Amerika Serikat, perbaikan ekonomi di Eropa yang ditandai dengan perbaikan di sisi permintaan domestic serta perbaikan dalam investasi yang menopang pertumbuhan di jepang (Departemen Keuangan Indonesia, 2016). Namun demikian perekonomian dibeberapa negara maju lainnya belum menunjukkan perbaikan secara menyeluruh. Pemulihan kawasan eropa masih 
lambat begitu juga dengan perekonomian Indonesia yang mana dihadapkan pada makin sulitnya likuiditas dunia sejalan dengan kebijakan pengurangan pembelian obligasi yang dilakukan oleh Bank Sentral AS.

Sejalan dengan pergerakan pergerakan perekonomian global, pertumbuhan ekonomi nasional pada tahun 2014 melambat menjadi 5,1 persen (Bappenas, 2016). Walaupun demikian pertumbuhan ekonomi Indonesia pada tahun 2015 diatas angka pertumbuhan ekonomi dunia sebesar 3,3 persen. Sinyal ini menunjukkan bahwa kinerja dan daya tahan ekonomi Indonesia masih mencapai diatas rata-rata. Dalam upaya peningkatan pertumbuhan ekonomi Indonesia, pemerintah mengeluarkan serangkaian paket - paket kebijakan yang mendorong kinerja seluruh pasar saham. Kemajuan pasar modal di suatu negara dijadikan tolak ukur untuk melihat kegairahan atau perkembangan dinamisnya bisnis dalam suatu negara yang dapat memberikan nilai tambah pada pendapatan negara yang berkaitan dengan keibjakan yang ditetapkan pemerintah. Untuk mendorong perkembangan pertumbuhan ekonomi di Indonesia, yang mana majoritas penduduk Indonesia adalah muslim dan terbesar didunia, kemajuan pasar modal syariah telah muncul dengan perkembangan pasar modal syariah melalui diterbitkannya reksa dana syariah oleh PT. Danareksa Investment Management pada 3 Jui 1997, Selanjutnya Bursa Efek Indonesia bekerja sama dengan PT. Dana reksa Investment Management meluncurkan Jakarta Islamic Index (JII) pada tanggal 3 Juli 2000, ditopang oleh fatwa mengenai pasar modal syariah pada tanggal 18 April 2001 oleh Dewan Syariah Nasional Majelis Ulama Indonesia (DSN - MUI) (Mansur, D.P, et al, 2016), serta obligasi syariah efektif mulai 30 Oktober 2002 (Dewi, A., 2014).

Munculnya pasar saham syariah adalah kunci untuk mengurangi risiko ketidak pastian dalam pasar modal konvensional dan juga mengurangai skandal keuangan di pasar modal internasional seperti kasus Enron, WorldCom, AOL, Walt Disney, dan banyak yang lainnya (Muhsinhar, 2011), tidak hanya itu, pasar saham syariah menampung masyarakat (muslim dan non muslim) dalam kegiatan memperoleh keuntungan dan risikonya, meningkatkan performa, kinerja dan sustainable dari perusahaan yang termasuk dalam bursa saham syariah sesuai dengan harga saham, serta mengurangi terjadinya spekulasi di pasar modal (Komariah, N., 2014). 


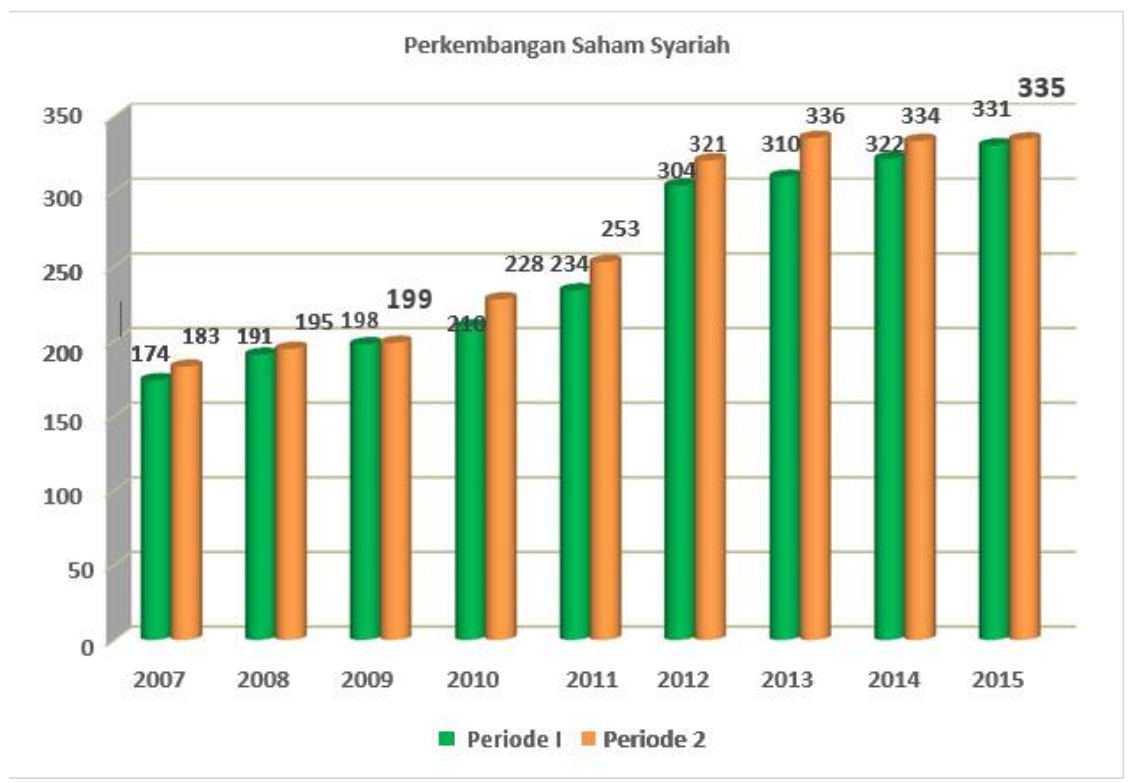

Gambar 1:

Statistika Saham Syariah, OJK * per November 2015 Sumber Data : OJK, 2015

Dilihat dari grafik diatas, saham syairah dari tahun 2007 sampai November 2015 mengalamai kenaikan yang significant meskipun kenaikan dari tahun 2014 ketahun 2015 tidak tinggi. Indikasi tersebut masih menunjukkan perkembangan berinvestasi terutama dalam perusahaan yang terjamin sesuai prinsip syariah yang mana sudah terseleksi oleh DSN - MUI (dewan syariah nasional - majelis ulama Indonesia)dan OJK (otoritas jasa keuangan) tentang proses, karakter dan perusahaan yang memenuhi syarat saham syariah yang disebut business screening dan juga penyeleksiaan pendapatan perusahaan yang disebut financial screening.

Dalam praktiknya sistem keuangan Islam sudah menyiapkan tempat untuk umat yang berkeinginan berinvestasi dalam bentuk pasar investasi keuangan yang bisa memberikan jaminan kehalalannya. Penjaminan tersebut diatur dalam dasar hokum pasar modal syariah di Indonesia yang mengacu pada peraturan otoritas jasa keuangan yang terdiri dari POJK Nomor 15/POJK.04/2015 tentang penerapan prinsip syariah di pasar modal, POJK Nomor 16/POJK.04/2015 tentang ahli syariah pasar modal, POJK Nomor 17/POJK.04/2015 tentang penerbitan dan persyaratan efek syariah berupa saham oleh emiten syariah atau perusahaan publik syariah, POJK Nomor 18/POJK.04/2015 tentang penerbitan dan persyaratan sukuk, POJK Nomor 19/POJK.04/2015 tentang penerbitan dan persyaratan reksa dana syariah dan POJK Nomor 20/POJK.04/2015 tentang penerbitan dan persyaratan efek beragun asset syariah. Juga didukung oleh fatwa DSN MUI nomer 20/DSN-MUI/IV/2001 tentang pedoman pelaksanaan investasi untuk reksa dana syariah beserta penyempurnaan 
peraturan Bapepam-LK Nomor IX.A. 13 tentang penerbitan efek syariah dan II.K.1 tentang kriteria dan penerbitan daftar efek syariah (OJK, 2016).

Sebagai upaya untuk pengembangan perekonomian Indonesia sangat diperlukannya peran investor yang mana Penelitian tentang peningkatan minat berinvestasi di pasar modal syariah telah ditelaah oleh Bapepam LK pada tahun 2011 yang mana faktor yang mempengaruhi minat berinvestasi dikelompokkan menjadi dua faktor yaitu internal dan eksternal. Faktor internal meliputi kehalalan investasi, diversifikasi investasi, return investasi, dan pengetahuan investor, sedangkan faktor eksternal meliputi regulasi, dan kondisi ekonomi atau sosial faktor ekonomi. Kajian dari penelitian Adik Putri Sarah (2014) berupa faktor risiko investasi, penerapan prinsip syariah, informasi produk, dan kepuasan investorKajian oleh Dede Puad M et al (2016) mengenai factor perbedaan gender, level pendapatan serta banyaknya kegiatan sosialisasi yang diterima mahasiswa terhadap minat berinvestasi di pasar modal syariah. Diikuti juga oleh faktor lain berupa motivasi dan pengetahuan tentang investasi (Kusmawati, 2011).

Kajian oleh Chambali M (2010) berupa faktor objective dan subjective. Faktor objective meliputi teknologi, harga, faktor produksi, dan permintaan akan barang pada masa datang, sedangkan faktor subjective yaitu pengalaman yang dialami investor baik positif maupun negative.kajian oleh Diah Lukita Sari (2008) berupa faktor usia, tingkat ekonomi dan peran kelompok referensi terhadap minat berinvestasi di pasar modal syariah khususnya pada reksa dana syariah yang mana didasarkan pada teori model hierarchy of effects dan teori dair Kotler tentang kotak hitam pembeli yaitu faktor faktor yang dapat mempengaruhi keputusan pembeli dari kebudayaan, social, invidu dan psikologi. Kajian oleh Fikri Indra Silmy (2011) berupa faktor persepsi, motivasi dan belajar terhadap keputusan investasi saham syariah. Kajian oleh Ani Dewi (2014) tentang faktor kebijakan dividen, suku bunga SBI dan nilai kurs terhadap investasi di Jakarta Islamic Index (JII). Dan juga kajian oleh Eka sri wahyuni (2015) tentang faktor teknikal yaitu berupa harga saham dan faktor fundamental berupa analisa suku bunga berkaitan dengan keputusan investor untuk berinvestasi di saham syariah Indonesia.

Penelitian mencoba untuk menganalisa permasalahan yang berkaitan dengan "ANALISA FAKTOR - FAKTOR YANG MEMPENGARUHI MINAT MASYARAKAT BERINVESTASI DI PASAR MODAL SYARIAH MELALUI BURSA GALERI INVESTASI UISI". Penelitian ini dilakukan untuk melihat lebih dalam mengenai faktor - faktor yang paling berpengaruh terhadap minat investasi berupa risiko berinvestasi, tingkat pendapatan (modal), motivasi, pengetahuan tentang investasi, persepsi, dan belajar di pasar modal syariah untuk investor yang melakukan transaksi di galeri investasi bursa saham investasi universitas internasional semen Indonesia. 
Adapun beberapa permasalahan yang akan dibahas adalah; Bagaimana pengaruh risiko terhadap minat investor berinvestasi di pasar modal syariah melalui galeri investasi bursa saham investasi universitas internasional semen Indonesia?; pertanyaan ini digunakan untuk mengetahui pengaruh risiko terhadap minat investor berinvestasi di pasar modal syariah melalui galeri investasi bursa saham investasi universitas internasional semen Indonesia. Selanjutnya, untuk mengetahui pengaruh tingkat pendapatan terhadap minat investor berinvestasi di pasar modal syariah melalui galeri investasi bursa saham investasi universitas internasional semen Indonesia maka permasalahan yang diajukan adalah bagaimana pengaruh tingkat pendapatan terhadap minat investor berinvestasi di pasar modal syariah melalui galeri investasi bursa saham investasi universitas internasional semen Indonesia?;

Mengetahui pengaruh motivasi terhadap minat investor berinvestasi di pasar modal syariah melalui galeri investasi bursa saham investasi universitas internasional semen Indonesia maka pertanyaan yang diajukan adalah bagaimana pengaruh motivasi terhadap minat investor berinvestasi di pasar modal syariah melalui galeri investasi bursa saham investasi universitas internasional semen Indonesia?;

Selanjutnya adalah bagaimana pengaruh pengetahuan tentang investasi terhadap minat investor berinvestasi di pasar modal syariah melalui galeri investasi bursa saham investasi universitas internasional semen Indonesia? Hal ini dipertanyakan untuk mengetahui pengaruh pengetahuan tentang investasi terhadap minat investor berinvestasi di pasar modal syariah melalui galeri investasi bursa saham investasi universitas internasional semen Indonesia.

Bagimana pengaruh persepsi terhadap minat investor berinvestasi di pasar modal syariah melalui galeri investasi bursa saham investasi universitas internasional semen Indonesia?; Mengetahui pengaruh persepsi terhadap minat investor berinvestasi di pasar modal syariah melalui galeri investasi bursa saham investasi universitas internasional semen Indonesia. Bagimana pengaruh belajar terhadap minat investor berinvestasi di pasar modal syariah melalui galeri investasi bursa saham investasi universitas internasional semen Indonesia? Berjutuan untuk Mengetahui pengaruh belajar terhadap minat investor berinvestasi di pasar modal syariah melalui galeri investasi bursa saham investasi universitas internasional semen Indonesia

\section{LANDASAN TEORI}

\section{Investasi}

Investasi didefinisikan sebagai saham penukaran uang dengan bentuk bentuk kekayaan lain seperti saham atau harta tidak bergerak yang diharapkan dapat ditahan selama periode waktu tertentu supaya menghasilkan pendapatan. Pada umumnya, 
investasi dibedakan menjadi dua yaitu investasi pada financial asset dan investasi pada real asset. Investasi financial asset dilakukan di pasar uang berupa sertifikat deposito, Surat Berharga Pasar Uang (SBPU) dan juga di pasar modal. Sedangkan investasi real asset dilakukan dengan membeli asset produktif, pendirian pabrik, pembukaan pertambangan, dan lainnya (Salim, H.S dan Sutrisno, B., 2008).

Investasi bisa dilakukan secara langsung dengan membeli langsung active keuangan yang dapat diperjual belikan di pasar uang, pasar modal atau pasar turunan. Sedangkan investasi yang tidak langsung dilakukan dengan membeli saham dari perusahaan investasi yang mempunyai portfolio aktiva keuangan dari perusahaan yang terdaftar di bursa efek Indonesia.

Orang yang melakukan investasi disebut investor, investor ada dua jenis yaitu investor individual dan investor institutional. Investor individual terdiri dari individu individu yang melakukan investasi sedangkan investor institutional terdiri dari perusahaan - perusahaan asuransi, lembaga penyimpanan semisal bank, lembaga simpan pinjam dan lembaga dana pension (Siahaan, N.M, 2011).

Dalam Islam, kegiatan berinvestasi termasuk kegiatan muamalah yang mana hukum asal dari kegiatan muamalah adalah mubah (boleh), sehingga berinvestasi dikatakan mubah (boleh) kecuali ada hukum akan larangan yang mengikutinya (haram). Kegiatan berinvestasi dalam Islam oleh Dadan Muttaqien (2009) merupakan kegiatan yang dilakukan oleh pemilik harta (investor) terhadap pemilik usaha (emiten) untuk memberdayakan pemilik usaha dalam melakukan kegiatannya, dimana pemilik harta (investor) berharap untuk memperoleh manfaat tertentu yang mana kegiatan pembiayaan dan investasi keuangan berdasarkan prinsip yang sama dengan kegiatan usaha lainnya yaitu memelihara prinsip kehalalan dan keadilan. Berinvestasi dengan menggunakan norma syariah, merupakan sebuah dari ilmu dan amal, oleh karena itu, investasi sangat dianjurkan bagi muslim. Hal tersebut dijelaskan di dalam Al-Qur'an surat al-hasyr ayat 18 sebagai berikut:

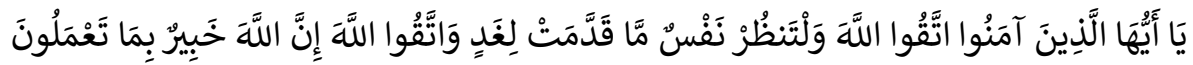

Artinya: Hai orang-orang yang beriman, bertakwalah kepada Allah dan hendaklah setiap diri memperhatikan apa yang telah diperbuatnya untuk hari esok (akhirat); dan bertakwalah kepada Allah, sesungguhnya Allah Maha Mengetahui apa yang kamu kerjakan.

Dari ayat diatas, penafsiran dari "hendaklah setiap diri memperhatikan apa yang telah diperbuatnya untuk hari esok (akhirat)" yaitu melakukan investasi akhirat dengan melakukan amal sholeh sejak dini untuk bekal di akhirat kelak. Tidak terbatas oleh perihal tersebut, investasi membawa kemakmuran dan kesejahteraan bagi pelakunya terutama untuk keturunannya yang mana sepeninggalnya untuk ahli waris keturunannya 
tidak ditinggalkan dalam keadaan miskin melainkan dalam keadaan lebih baik (kaya) sebagaimana dijelaskan dalam surat An-Nisa ayat 9:

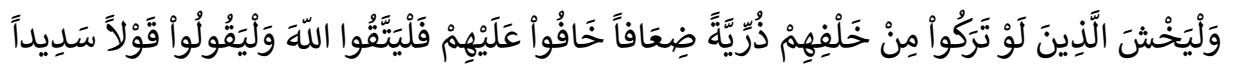

Artinya: Dan hendaklah takut kepada Allah orang-orang yang seandainya meninggalkan dibelakang mereka anak-anak yang lemah, yang mereka khawatir terhadap (kesejahteraan) mereka. Oleh sebab itu hendaklah mereka bertakwa kepada Allah dan hendaklah mereka mengucapkan perkataan yang benar.

Dari ayat diatas, dijelaskan bahwa pelarangan untuk meninggalkan keturunan dalam keadaan lemah (miskin). Penggunaan investasi tidak hanya untuk kepentingan diri sendiri melainkan untuk kemaslahatan (kesejahteraan) bersama, sebagaimana peringatan dari Al-Qur'an surat At-Taubah ayat 85:

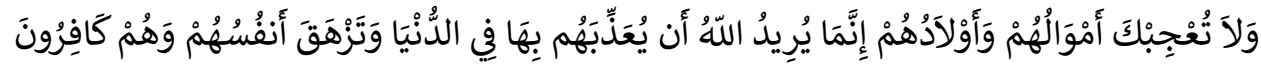

Artinya: Dan janganlah harta benda dan anak-anak mereka menarik hatimu.

Sesungguhnya Allah menghendaki akan mengazab mereka di dunia dengan harta dan anak-anak itu dan agar melayang nyawa mereka, dalam keadaan kafir.

Peringatan dari ayat diatas diperuntukkan untuk investor yang hanya mencari keuntungan pribadi semata. Peringatan tersebut untuk menelaah tujuan investasi yang diharapkan bukan hanya untuk kepentingan pribadi, tidak melanggar rambu-rambu syariah berupa terbebas dari unsur riba, gharar (ketidak pastian / spekulasi), maysir (judi), haram, subhat (diragukan), transaksi memberi nilai manfaat dan menghindari transaksi yang zalim, uang sebagai alat pertukaran bukan komoditas perdagangan, transaksi yang transparan yang tidak menimbulkan kerugian atau unsur penipuan, risiko yang harus dikelola sehingga tidak melebihi kemampuan penanggung risiko dan diperuntukkan untuk kemaslahatan (kesejahteraan) bersama bagi investor dan penerima modal yang jika ditelaah lagi membantu mengurangi jumlah pengangguran dan perekonomian negara.

\section{Konsep Dasar Pasar Modal Syariah}

Definisi pasar modal sesuai dengan undang - undang Nomor 8 Tahun 1995 tentang Pasar Modal (UUPM) adalah kegiatan yang bersangkutan dengan penawaran umum dan perdagangan efek perusahaan public yang berkaitan dengan efek yang diterbitkannya, serta lembaga dan profesi yang berkaitan dengan efek. Berdasarkan definisi tersebut, terminology pasar modal syariah dapat diartikan sebagai kegiatan dalam pasar modal sebagaimana yang diatur dalam UUPM yang tidak bertentangan dengan prinsip syariah. Oleh karena itu, pasar modal syariah bukanlah suatu system yang terpisah dari system pasar modal secara keseluruhan. Secara umum, kegiatan pasar modal syariah tidak memiliki perbedaan dengan pasar modal konvensional, namun terdapat beberapa karakteristik khusus Pasar Modal Syariah yaitu bahwa produk dan mekanisme transaksi tidak bertentangan dengan prinsip-prinsip syariah. 
Penerapan prinsip syariah dipasar modal tentunya bersumberkan pada Al-Qur'an sebagai sumber hukum tertinggi dan Hadits Nabi Muhammad SAW. Selanjutnya, dari kedua sumber hukum tersebut, para ulama melakukan penafsiran yang kemudian disebut ilmu fiqih. Salah satu pembahasan dalam ilmu fiqih adalah pembahasan tentang muamalah, yaitu hubungan diantara sesame manusia terkait perniagaan. Berdasarkan itulah kegiatan pasar modal syariah dikembangkan dengan basis fiqih muamalah. Terdapat kaidah fiqih muamalah yang menyatakan bahwa pada dasarnya, semua bentuk muamalah boleh dilakukan kecuali ada dalil yang mengharamkannya. Konsep inilah yang menjadi prinsip pasar modal syariah di Indonesia.

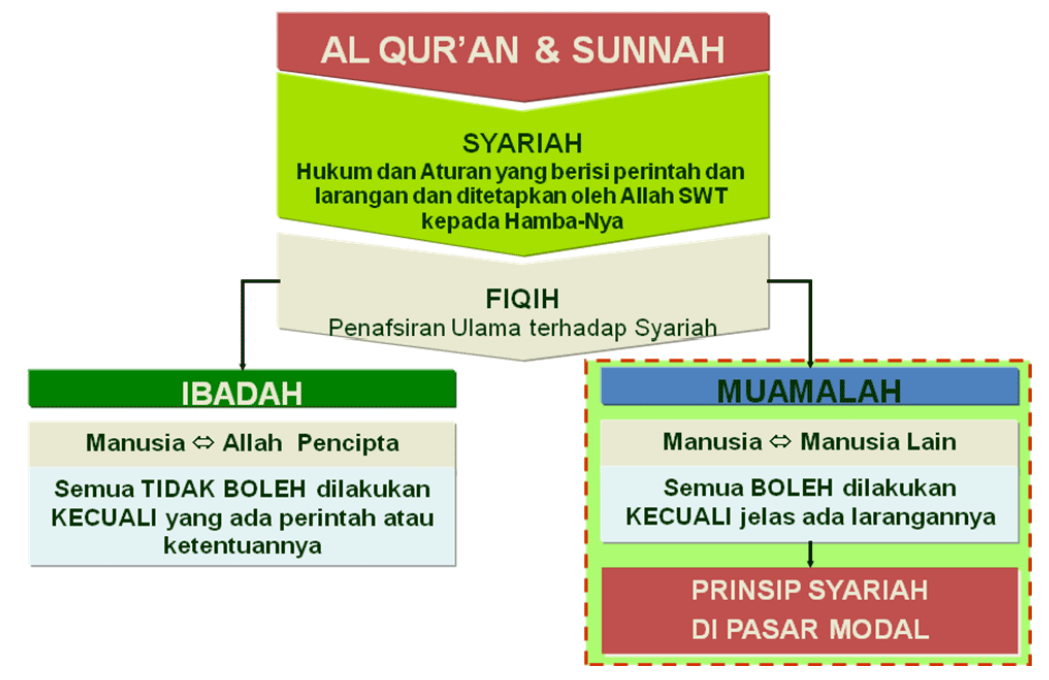

Sumber: Otoritas Jasa Keuangan, 2014 www.ojk.go.id

\section{Gambar 2}

Sumber Hukum Pasar Modal Syariah

Sebagai bagian dari system pasar modal Indonesia, penerapan prinsip-prinsip syariah di pasar modal mengacu kepada Peraturan Otoritas Jasa Keuangan yang terdiri dari:

1. POJK Nomor 15/POJK.04/2015 tentang Penerapan Prinsip Syariah di Pasar Modal

2. POJK Nomor 16/POJK.04/2015 tentang Ahli Syariah Pasar Modal

3. POJK Nomor 17/POJK.04/2015 tentang Penerbitan dan Persyaratan Efek Syariah Berupa Saham oleh Emiten Syariah atau Perusahaan Publik Syariah

4. POJK Nomor 18/POJK.04/2015 tentang Penerbitan dan Persyaratan Sukuk

5. POJK Nomor 19/POJK.04/2015 tentang Penerbitan dan Persyaratan Reksa Dana Syariah dan

6. POJK Nomor 20/POJK.04/2015 tentang Penerbitan dan Persyaratan Efek Beragun Aset Syariah 


\section{Produk Syariah di Pasar Modal}

Produk syariah di pasar modal antara lain berupa surat berharga atau efek. Berdasarkan undang-undang Nomor 8 Tahun 1995 tentang Pasar Modal (UUPM), Efek adalah surat berharga, yaitu surat pengakuan utang surat berharga komersial, saham, obligasi, tanda bukti utang. Unit penyertaan kontrak investasi kolektif kontrak berjangka atas Efek, dan setiap derivative dari Efek. Sejalan dengan definisi tersebut, maka produk syariah yang beruapa efek harus tidak bertentangan dengan prinsip syariah. Oleh karena itu efek tersebut dikatakan sebagai Efek Syariah. Dalam peraturan Bapepam dan Lk Nomor IX.A.13 tentang Penerbitan Efek Syariah disebut bahwa Efek Syariah adalah Efek sebagaimana dimaksud dalam UUPM dan peraturan pelaksanaannya yang akad, cara, dan kegiatan usaha yang menjadi landasan pelaksanaannya tidak bertentangan prinsipprinsop syariah di pasar modal. Sampai dengan saat ini, Efek Syariah yang telah diterbitkan di pasar modal Indonesia meliputi Saham Syariah, Sukuk dan Unit Penyertaan dari Reksa Dana Syariah.

\section{Perilaku Investor}

Banyak faktoryang mempengarui investor untuk berinvestasi. Dalam penilitian ini, yang menjadi factor investor untuk berinvestasi berupa risiko, level pendapatan, motivasi, pengetahuan tentang investasi, persepsi, motivasi, dan belajar.

\section{Risiko}

Dalam berinvestasi mengandung unsur ketidakpastian atau risiko. Investor tidak mengetahui dengan pasti hasil dari investasi yang dilakukannya. Dalam kondisi tersebut, investor dikatakan mengalami risiko. Dalam kondisi tersebut, investor tidak hanya mengharapkan keuntungan semata. Apabila investor mengharapkan keuntungan yang tinggi, maka investor harus siap menanggung risiko yang tinggi pula. Kemudahan dari berinvestasi pada sekuritas adalah kemudahan untuk membentuk portfolio investasi yaitu dapat melakukan difersifikasi investasi (pemilihan lebih dari satu investasi) pada berbagai kesempatan investasi (Asba, M.Y.A., 2013).

Dalam investasi syariah, risiko tidaklah serupa dengan ketidakpastian (uncertainty). Keduanya merupakan istilah yang serupa tapi tidak sama. Keserupaan keduanya terletak pada pengertian mengenai adanya suatu kejadian yang belum pasti di masa yang akan datang. Untuk istilah uncertainty, ketidakpastian tersebut merujuk pada kejadian-kejadian yang tidak diharapkan yang tidak diperkirakan (unexpected risk), sedangkan risiko dalam hal ini dimaksudkan sebagi sesuatu yang dapat diperkirakan (expected risk). Selanjutnya, perbedaan keduanya terletak pada estimasi atas ketidakpastian tersebut. Unexpected risk dalam uncertainty kemungkinan muncul lebih 
dari satu, namun probabilitas kemunculannya tidak dapat diketahui secara kuantitatif, sedangkan risiko tingkat ketidakpastiannya dapat diukur secara kuantitatif.

Pengukuran risiko investasi secara kuantitatif dalam hal ini dapat dilakukan dalam kondisi tersedianya informasi, sehingga perbedaan tersebut mengerucut pada ketersediaan informasi. Dalam kajian fiqih muamalah, istilah untuk menyebut ketidakpastian adalah gharar dan tadlis. Sepertihalnya uncertainty dan risk. Seringkali kedua kata tersebut dipertukarkan sehingga dikatakan uncertainty dan risk adalah gharar. Padahal keduanya terdapat perbedaan yang mendasar sepertihalnya pembahasan diatas yaitu tentang penyediaan informasi. Dalam gharar kurangnya pengetahuan informasi dialami oleh kedua pihak yang berakad, sedangkan dalam tadlis hanya dialami oleh salah satu pihak.

Ketidakjelasan terkait objek akad menjadi dilarangnya akad menurut ulama yaitu meliputi 1) jenis, 2) spesifikasi, 3) atribut, 4) kuantitas, 5) esensi, dan 6) waktu penyerahan. Yang mana risiko tersebut membuat garis besar pembagian investor (Irkhami, N., 2010).

Ada tiga jenis investor yang jika dikaitkan dengan preferensinya yaitu 1) investor yang menyukai risiko (risk seeker), 2) investor yang netral terhadap risiko (risk neutral), dan 3) investor yang tidak menyukai risiko (risk averse) (Halim, 2005). Tindakan minimal yang dilakukan untuk memanfaatkan kelebihan dananya adalah menabung atau mendepositokan. Tindakan minimal ini dilakukan oleh orang yang tergolong takut risiko (risk averse). Berbeda halnya dengan orang yang tergolong penantang risiko (risk taker), mereka cenderung untuk menginvestasikan dananya pada bentuk - bentuk investasi yang memberikan keuntungan yang lebih besar meskipun risiko yang dihadapi juga besar, seperti investasi pada saham (Kusmawati, 2011).

Dalam kaitannya dengan investasi, terdapat korelasi langsung antara pengembalian dengan risiko, yaitu semakin tinggi pengembalian, semakin tinggi risiko. Oleh karena itu, investor harus menjaga tingkat risiko dengan pengembalian yang seimbang (Siahaan, N.M, 2011).

Dari penilaian investasi model Markowitz menjelaskan bahwa risiko investasi saham terdiri dari risiko tidak sistematis dan risiko sistematis. Risiko tidak sistematis adalah risiko yang terkait dengan fluktuasi dan siklus bisnis dari industry tertentu. Setiap industry memiliki karakteristik risiko khusus yang dipengaruhi variable - variable ekonomi secara specific. Sehingga perusahaan - perusahaan yang jenis usahanya sama akan mendapatkan risiko tidak sistematis yang sama. Risiko ini juga biasa disebut dengan risiko bisnis. Risiko bisnis dapat dikurangi dengan diversifikasi. Sedangkan risiko sistematis merupakan risiko eksternal dari sebuah bisnis seperti inflasi, keadaan ekonomi global dan sebagainya. risiko tersebut dapat diklasifikasikan menjadi empat hal:

a. Tidak mendapatkan dividen 
b. Kerugian saat penjualan saham (capital loss)

c. Risiko likuiditas, yaitu liquiditas peusahaan yang minim. Sehingga saat dividen harus dibagikan, investor tidak mendapatkan dividen karena likuiditas perusahaan yang minim

d. Delisting atau penghapusan saham - saham yang dinilai tidak produktif, yang menyebabkan tidak lakunya saham dibursa saat akan dijual (Silmy, F.I., 2011).

Risiko likuiditas juga ditekankan oleh Moch Chambali (Chambali, M., 2010) untuk obligasi yang mana ketika ada masalah dalam obligasi atau pasar masih belum paham dengan keadaan obligasi, maka investor mengalami kesulitan untuk melikuidnya menjadi dana. Sehingga timbul aksi jual yang sengaja menekan harga dibawah par.

Berdasarkan penelitian Makaryanawati (2016), risiko likuiditas merupakan satu faktor yang menentukan risiko investasi. Likuiditas diukur dengan rasio keuangan. Jika rasio likuiditas tinggi, maka perusahaan akan semakin diminati investor. Hal ini mengakibatkan harga saham naik dan risiko investasi menjadi tinggi dan sebaliknya. Tidak hanya risiko yang mempengaruhi investor untuk berinvestasi, terdapat faktor lain yang mempengaruhinya yaitu level pendapatan.

\section{Level Pendapatan}

MYA Asba (2013) menyebutkan faktor yang mempengaruhi konsumen (investor) adalah faktor kepribadian yaitu keadaan ekonomi investor (level pendapatan). Investasi pada pokoknya didasarkan atas teori produktivitas batas (marginal productive) dari faktor produksi modal (capital). Dalam teori ini, besarnya modal yang akan diinvestasikan dalam proses produksi ditentukan oleh produktivitas marginalnya (perusahaan). Sehingga investor akan terus meningkatkan investasinya bilamana produktivitas batas dari investasi masih lebih tinggi dari pada tingkat bunga yang akan diterima (Pratama, D.I., 2013). Dalam kaitannya, jika produktivitas perusahaan terbuka atau eminten meningkat dan mendapatkan hasil yang maksimal sehingga menjadikan peningkatan pembagian dividen ke investor, secara tidak langsung, pendapatan investor akan meningkat.

Peningkatan produktivitas penerima modal akan meningkatkan nilai harga saham sehingga bagi investor yang menyukai resiko tinggi untuk mendapatkan return yang tinggi akan menambah jumlah investasinya kepada emiten atau perusahaan terbuka tersebut. Yang dalam kaitannya, pendapatan investor akan berhubungan significant positive terhadap minat berinvestasi diiringi dengan peningkatan produktivitas penerima modal teruntuk investor risk seeker. Di lain sisi, bagi investor risk averse dan risk neutral mungkin akan berbeda kondisi. Oleh Karena itu, dalam penelitian ini akan mengupas 
hubungan tersebut. Faktor lain yang berkaitan dengan minat investor berinvestasi adalah motivasi.

\section{Motivasi}

Motivasi dapat didefinisikan sebagai proses dimana individu mengenal kebutuhannya dan mengambil tindakan untuk memuaskan kebutuhan tersebut. Dalam kandungannya bahwa motivasi merupakan suatu proses dan proses ini dapat menjelaskan perbedaan dalam intensitas perilaku konsumen (investor). Kandungan lainnya dari definisi tersebut bahwa motivasi merupakan dorongan, yaitu dorongan bagi manusia untuk mengambil tindakan tertentu dalam upaya memuaskan kebutuhannya. David MecClelland mengembangkan teori motivasi yang dikenal dengan McClelland's theory of learned needs. Teori ini menyatakan bahwa ada tiga kebutuhan dasar yang memotivasi seseorang individu untuk berperilaku yaitu 1) kebutuhan untuk sukses, 2) kebutuhan untuk afiliasi (membina hubungan sesame), 3) kebutuhan kekuasaan (2013).

Dalam kaitan teori tersebut dalam investasi, investor termotivasi untuk berinvestasi dalam pemenuhan kebutuhan diri (kesuksesan dan return) juga membantu perkembangan perekonomian dalam afiliasi dengan eminen atau perusahaan terbuka, dan juga untuk kebutuhan kekuasaan yang terkait dengan menjaga keterpenuhan kebutuhan diri atau keluarga dalam jangka waktu yang lama (keturunan) dan bisa juga ditafsirkan untuk pengembangan kekuasaan dalam investasi dalam rangka menjaga kestabilan perekonomian dengan menjadi majoritas pemegang saham.

Di lain teori, berdasarkan teori Hull dapat diambil kesimpulan bahwa motivasi seseorang sangat ditentukan oleh kebutuhan dalam dirinya dan faktor kebiasaan dari pengalaman belajar sebelumnya. Sepertihalnya pengalaman investor yang menjadikan kekuatan motivasinya untuk berinvestasi di pasar modal. Berdasarkan teori lapangan dari kurt lewin, teori tersebut mengemukakan bahwa perilaku seseorang merupakan fungsi dari seseorang terhadap lingkungannya. Dalam kaitannya dengan investasi, investor dipengaruhi oleh lingkungan investasi dan lingkungan pengembangan berinvestasi sehingga termotivasi untuk berinvestasi (Silmy, F.I., 2011). Dalam pengembangan motivasi tersebut, diperlukan faktor lain yang mempengaruhi investor berinvestasi yaitu pengetahun tentang investasi.

\section{Pengetahuan}

Dalam proses keputusan berinvestasi, diperlukannya pengetahuan tentang pengembalian, resiko, tipe produk investasi, untuk mendapatakan investasi yang lengkap (Siahaan, N.M, 2011). Menurut Fikri (2011) dalam berinvestasi pada level basic, para investor harus mengenal istilah - istilah dalam pasar modal seperti saham, obligasi, reksadana dan sebaginya. Kemudian di level intermediate, dituntut untuk pengetahuan 
tentang analisis teknikal dan fundamental saham yang mana juga dilakukan simulasi perdagangan dalam bursa efek sehingga lebih teknis mengetahui perdagangan dalam bursa efek.

Di level advance, investor sudah memiliki rekening efek yang langsung bergerak dalam pasar modal syariah, obligasi, dan perkembangan pasar. Menurut Kusmawati (2011) dalam penelitiannya menyatakan bahwa untuk melakukan investasi di pasar modal diperlukan pengetahuan yang cukup, pengalaman serta naluri bisnis untuk menganalisis efek - efek mana saja yang akan dibeli. Pengetahuan yang memadai sangat diperlukan, seperti pada instumen investasi saham, hal - hal yang sangat penting untuk diketahui adalah bagaimana menilai kinerja perusahaan yang bersangkutan untuk beberapa tahun belakangan. Pengetahuan investasi sangat diperlukan untuk menghindari terjadinya kerugian saat berinvestasi di pasar modal. Pengetahuan investasi juga sangat diperlukan untuk memperoleh return yang maksimal dari investasi yang dilakukan. Untuk mengembangkan lebih luas lagi minat investor selain pengetahuan, faktor persepsi investor terhadap pasar modal syariah.

\section{Persepsi}

Preferensi diartikan sebagai pilihan suka atau tidak suka seseorang terhadap suatu produk barang atau jasa yang digunakan. Dalam arti yang lain, persepsi merupakan seperangkat objek yang dinilai sesuai atau mendekati kesesuaian dengan persyaratan yang dikehendaki oleh konsumen (investor). Dalam teori persepsi dapat digunakan untuk menganalisis tingkat kepuasan bagi konsumen (investor) dalam kaitannya minat investor untuk berinvestasi. Menurut willian j. staton persepsi adalah pertalian investor berdasarkan pengalaman lalu melalui stimulasi yang diterima indra (Mustofa, 2015). Rangsangan yang kuatlah yang dapat memikat persepsi orang. Sehingga untuk menarik persepsi orang, dibutuhkan pesan yang menonjol dibandingkan dengan produk lainnya. Diperlukannya rangsangan untuk investor bukan hanya promosi akan tetapi segala yang dibutuhkan investor. Image atau gambaran suatu produk sangat penting di mata konsumen (investor).

Sebagaimana halnya dengan image label "syariah" dapat menimbulkan menarik konsumen untuk menggunakan barang atau jasa tersebut sepertihalnya perkembangan produk syariah dibidang perbankan, pasar modal dan lain sebaginya. Dalam penelitian Fikri (2011), menghasilkan persepsi bahwa perkembangan saham syariah sangat pesat, saham syariah diperuntukkan untuk semua pihak, peningkatan investor berinvestasi di saham syariah, pergerakan sasham syariah sama dengan saham lainnya, dan terdapat segi keuntungan dan resiko dalam saham syariah. Dengan kata lain, persepsi tentang pasar saham syariah atau pasar modal syariah menghasilkan hubungan postif dengan 
peningkatan minat investor untuk berinvestasi yang diartikan semakin bertumbuhnya pasar modal syariah, meningkat pula investor yang berinvestasi.

Dari penelitian Moch Chambali (2010) tersebut memberikan hasil bahwa semakin tinggi derajat persepsi investor terhadap keamanan atas risiko pada produk investasi syariah (sukuk SR 001), semakin tinggi minat berinvestasi pada produk investasi syariah (sukuk SR 001). Ketika investor mendalami lebih dalam tentang persepsi pasar modal syariah, diperlukan factor lain untuk meningkatkan minat investasi yaitu belajar.

\section{Belajar}

Belajar adalah perubahan muatan dan organisasi dalam memori jangka panjang yang mana belajar merupakan hasil dari informasi yang telah didapatkan sebelumnya. Factor belajar dipengaruhi oleh beberapa pengaruh yaitu 1) pengaruh keadaan yang mana mengacu pada pembelajaran berbasi gabungan stimulus atau rangsangan, 2) pengaruh classical yaitu terbentuknya respond dan stimulus yang dipelajari investor bukanlah informasi melainkan emosi atau respon afektif, 3) importance yaitu semakin penting individu ingin mempelajari, semakin efektif dan efisien individu tersebut dalam proses pembelajaran, 4) reinforcement yaitu sesuatu yang meningkatkan kemungkinan bahwa suatu respon akan diulangi diwaktu yang akan datang sebagi penguat, 5) punishment (hukuman) yang mana menurunkan kemungkinan akan pengulangan respon dimasa yang akan datang, punishment dilakukan untuk mengetahui hal penting dari pengalaman yang dilakukan dengan dibantu kekuatan pendorong, jika tidak akan mengurangi minat investor untuk berinvestasi terutama bagi investor averse. 6) repetition yaitu peningkatan kekuatan dan kecepatan pembelajaran semakin banyak waktu yang tertuang untuk mendapatkan informasi, semakin besar kemungkinan untuk mempelajari investasi lebih baik dan dalam serta effektif dan efficient (2011).

Pengaruh dari belajar tersebut akan meningkatkan kualitas investor untuk menganalisa lebih baik dan tajam tentang pasar modal terutama didalam perkembangan pasar modal syariah, sehingga dapat membedakan dengan baik antara pasar modal syariah dengan konvensional yang mana investor akan mendapatkan ketenangan dari berinvestasi baik dari informasi yang akurat dan lengkap serta minat untuk berinvestasi di pasar modal syariah.

\section{METODE PENELITIAN}

Jenis penelitian yang digunakan adalah penelitian kuantitatif. Penelitian kuantitatif adalah penelitian yang berkonsentrasi dalam pengujian teori - teori melalui variable penelitian dalam bentuk angka dan kemudian melakukan analisa data dengan proses statistika baik manual maupun dengan peranti lunak computer. Pada penelitian kuantitatif, teori atau paradigm teori digunakan untuk menuntun peneliti menemukan 
masalah penelitian, menemukan hipotesis, konsep, metodologi dan menemukan alat analisa data (Bungin, B, 2008). Kelebihan dari kuantitatif adalah sebagai alat ukur untuk menguji dugaan atau hepotesis dari kualitatif, serta memberikan justifikasi signifikan terhadap temuan penelitian berdasarkan uji statistic (Chambali, M., 2010).

\section{Sumber Data}

Sumber data yang digunakan dalam penelitian ini adalah data primer yaitu menggunakan metode angket yang mana dalam pelaksanaannya dilaksanakan dengan cara menyebarkan kuesioner pada responden secara langsung dan tidak langsung yaitu melalui google form kuesioner. Pada responden secara langsung, responden diminta memberikan pendapat atau jawaban berupa kuesioner tertutup begitu juga responden secara tidak langsung yaitu responden memberikan pendapat melalui kuesioner secara email atau perangkat lunak yang dilakukan secara online melalui google form kuesioner.

Kuesioner adalah teknik pengumpulan data dengan menggunakan daftar pertanyaan yang sifatnya tertutup, yaitu jawabannya telah tersedia sehingga responden tinggal memilih jawaban yang diinginkan. Pengukuran kuesioner digunakan dengan skala likert's yaitu pengukuran kuesioner berdasarkan tanggapan atau respon seseorang tentang objek social dimana setiap instrument jawaban mempunyai gradasi dari sangat positif sampai sangat negative (Suliyanto, 2010).

Penelitian dilakukan pada investor yang melakukan transaksi di galeri investasi bursa saham investasi universitas internasional semen Indonesia beserta pelatihan pasar modal yang diselenggarakan oleh sekuritas mandiri di universitas internasional semen Indonesia kurang lebih 200 reponden pada 20 juni 2016. Sebagai penilaian atas populasi yang ada, digunakan teknik pengambilan sampel yaitu teknik simple random sampling yaitu memberikan kesempatan yang sama pada populasi untuk menjadi sampel dalam penelitian. Dalam teknik ini, bahwa subjek penelitian berseifat homogen. Jumlah sampel yang diambil menggunakan persamaan Slovin, yaitu: $n=N / N \cdot d^{2}+1$. Keterangan: $n=$ jumlah sampel, $\mathrm{N}=$ jumlah populasi, $d=$ presisi (5\%). Maka $\mathrm{n}=200 / 200 \cdot 0,05^{2}+1=$ 133,33 jadi nilai sampel yang harus diambil dalam penelitian ini adalah 133,33 dibulatkan menjadi 133 orang (responden). Waktu pelaksanaan penelitian dilaksanakan dari bulan Maret 2016 sampai dengan Oktober 2016.

\section{Teknik Analisis Data}

Uji Validitas Dan Reliabilitas Kuesioner

Keabsahan atau kesahihan suatu hasil penelitian social sangat ditentukan oleh alat ukur yang digunakan, apabila alat ukur yang dipakai. Apabila alat ukur yang dipakai tidak valid dan tidak dapat dipercaya, hasil penelitian yang diperoleh tidak akan menggambarkan keadaan yang sesungguhnya. Untuk mengatasi hal tersebut, diperlukan 
dua macam pengujian yaitu test of validity (uji keabsahan) dan test of reliability (uji kehandalan) guna menguji kesungguhan jawaban responden.

Uji Keabsahan (Test Of Validity)

Analisis uji validitas dalam penelitian ini dilakukan dengan menggunakan korelasi Pearson. Teknik untuk menguji validitas instrument tiap variable dilakukan dengan cara mengkorelasikan tiap skor item instrument dengan total skor dari jumlah item instrument tersebut. Indikatornya adalah apabila nilai $\mathrm{p}$ (probabilitas) korelasi tersebut signifikan, maka instrument tersebut valid, sebaliknya apabila tidak signifikan maka item instrument tersebut tidak valid dan harus di drop. Signifikan tiap sector item ditetapkan dengan korelasi product moment melebihi 0.3 atau korelasi product moment lebih besar dari r-table. Hal ini bertujuan untuk memberikan dukungan bahwa butir - butir pengukuran yang dijadikan indicator konstruk terbukti memiliki validitas isi (content validity) yaitu butir - butir pengukuran tersebut merupakan alat ukur yang mencukup dan representative yang telah sesuai dengan konsep teoritis.

Analisis Faktor

Metode analisis yang digunakan dalam penelitian ini menggunakan analisis factor. Analisis factor adalah prosedur untuk mengidentifikasi item atau variable berdasarkan kemiripannya. Kemiripan tersebut ditunjukkan dengan nilai korelasi yang tinggi. Item yang memiliki korelasi yang tinggi akan membentuk satu kerumunan factor. Kebanyakan analisis factor digunakan untuk mengidentifikasi sejumlah factor yang relative kecil yang dapat digunakan untuk menjelaskan sejumlah besar variable yang saling berhubungan. Sehingga variable - variable dalam satu factor mempunyai korelasi yang tinggi, sedangkan korelasi dengan variable - variable pada factor lain relatif rendah. Dalam penelitian ini menggunakan software e-views (statistika software) untuk menganalisanya. Dalam melakukan analisis, diperlukan proses analisis factor yaitu 1) menentukan variable apa saja yang akan dianalisis, 2 ) menguji variable - variable yang telah ditentukan, 3) melakukan proses inti pada analisis factor yaitu factoring, 4) interpretasi atas factor yang telah terbentuk, khususnya member nama factor yang terbentuk tersebut, 5) validasi atas hadil factor untuk mengetahui apakah factor yang terbentuk valid. Selanjutnya dilakukan pengujian variable yang telah ditentukan dengan melakukan pengukuran metode test yaitu melalui dua pendekatan.

Analisis Regresi Linear Berganda

Setelah menganalisa hubungan korelasi antara variable, dilanjutkan dengan analisis regresi berganda untuk melihat pengaruh variable bebas terhadap variable terikat. Persamaan regresi yang digunakan adalah sebagai berikut: $Y=a+b 1 X 1+b 2 X 2$ $+b 3 \times 3+b 4 \times 4+b 5 \times 5+b 6 \times 6+e$ 
Dimana $Y=$ minat berinvestasi, $a=$ konstanta, $X 1=$ risiko berinvestasi, $X 2=$ level pendapatan, $\mathrm{X} 3=$ motivasi, $\mathrm{X} 4=$ pengetahuan tentang investasi, $\mathrm{X} 5=$ persepsi, $\mathrm{X} 6=$ belajar, b1-6 = koefisien regresi, e = error.

\section{HASIL DAN PEMBAHASAN}

\section{Profil Galeri Investasi Bursa Saham Investasi Universitas Internasional Semen Indonesia}

Galeri investasi bursa saham investasi universitas internasional semen Indonesia dibuka pada tahun 2015 dan dibuka untuk umum. Di galeri investasi bursa saham UISI dapat membuka akun untuk membeli saham dibantu penjelasan oleh mahasiswa UISI yang ditugaskan disana dan juga diadakan pelatihan investasi oleh mandiri securitas tentang berinvestasi secara bertahap.

\section{Hasil Uji Validitas dan Reliabilitas \\ Uji Validitas}

Peneliti memberikan 47 pernyataan kepada 133 responden dan menguji validitas dan reliabilitas dari seluruh pernyataan tersebut. Kuesioner terbagi menjadi 7 variabel yaitu variable investasi, risiko, pendapatan, motivasi, pengetahuan, persepsi, dan belajar. Untuk variabel investasi memiliki 9 indikator, risiko memiliki 6 indikator, pendapatan memiliki 4 indikator, motivasi memiliki 9 indikator, pengetahuan memiliki 5 indikator, persepsi memiliki 7 indikator, dan belajar memiliki 7 indikator. Dari ketujuh variabel tersebut, peneliti menggunakan 4 variabel dengan indikatorny yaitu variabel persepsi, motivasi, belajar, dan investasi merujuk pada penelitian Fikri.I.S, 2011. Variabel lainnya, peneliti melakukan trial indikator pernyataan.

\section{Uji Reliabilitas}

\section{Tabel 4.1}

Reliability Statistics

\begin{tabular}{|r|r|}
\hline $\begin{array}{c}\text { Cronbach's } \\
\text { Alpha }\end{array}$ & N of Items \\
\hline, 899 & 31 \\
\hline
\end{tabular}

Sumber : Data primer yang diolah

Dari tabel 4.1 diatas menjelaskan tentang uji relibilitas antara indikator yang mendukung penelitian. Dari nilai reliabilitas tersebut dengan menggunakan metode cronbach's alpha memberikan nilai 0,899 atau 89,9\% yang menandakan kekuatan realibilitas antar indikator kuat dan tinggi. 


\section{Hasil Pengujian Hipotesis \\ Korelasi}

Tabel 4.2

Model Summary

\begin{tabular}{|l|c|r|r|r|}
\hline Model & $\mathrm{R}$ & $\begin{array}{c}\mathrm{R} \\
\text { Square }\end{array}$ & $\begin{array}{c}\text { Adjusted } \\
\text { R Square } \\
\text { Error of } \\
\text { the } \\
\text { Estimate }\end{array}$ \\
\hline 1 &, $921^{\mathrm{a}}$ &, 849 &, 842 &, 204 \\
\hline
\end{tabular}

a. Predictors: (Constant), belajar, motivasi, pendapatan, persepsi, risiko, pengetahuan

b. Dependent Variable: DV investasi

Sumber : Data primer yang diolah

Pada tabel 4.2 nilai korelasi (R) antara variabel belajar, motivasi, pendapatan, persepsi, risiko dan pengetahuan terhadap variabel investasi saham syariah adalah 0,921 atau $92,1 \%$. Hubungan tersebut dikatakan sangat kuat, sesuai dengan metodologi penelitian.

\section{Koefisien Determinasi $\left(\mathbf{R}^{2}\right)$}

Dari tabel 4.15 diatas menunjukkan $\mathrm{R}^{2}$ sebagai tingkat koefisien determinasi dengan nilai 0,849 atau $84,9 \%$. Angka tersebut menunjukkan bahwa variabel belajar, motivasi, pendapatan, persepsi, risiko, dan pengetahuan secara bersama - sama memiliki pengaruh terhadap variabel investasi saham syariah sebesar $84,9 \%$. Dengan demikian terdapat $15,1 \%$ dipengaruhi oleh variabel lainnya.

\section{Model Regresi}

Tabel 4.3 


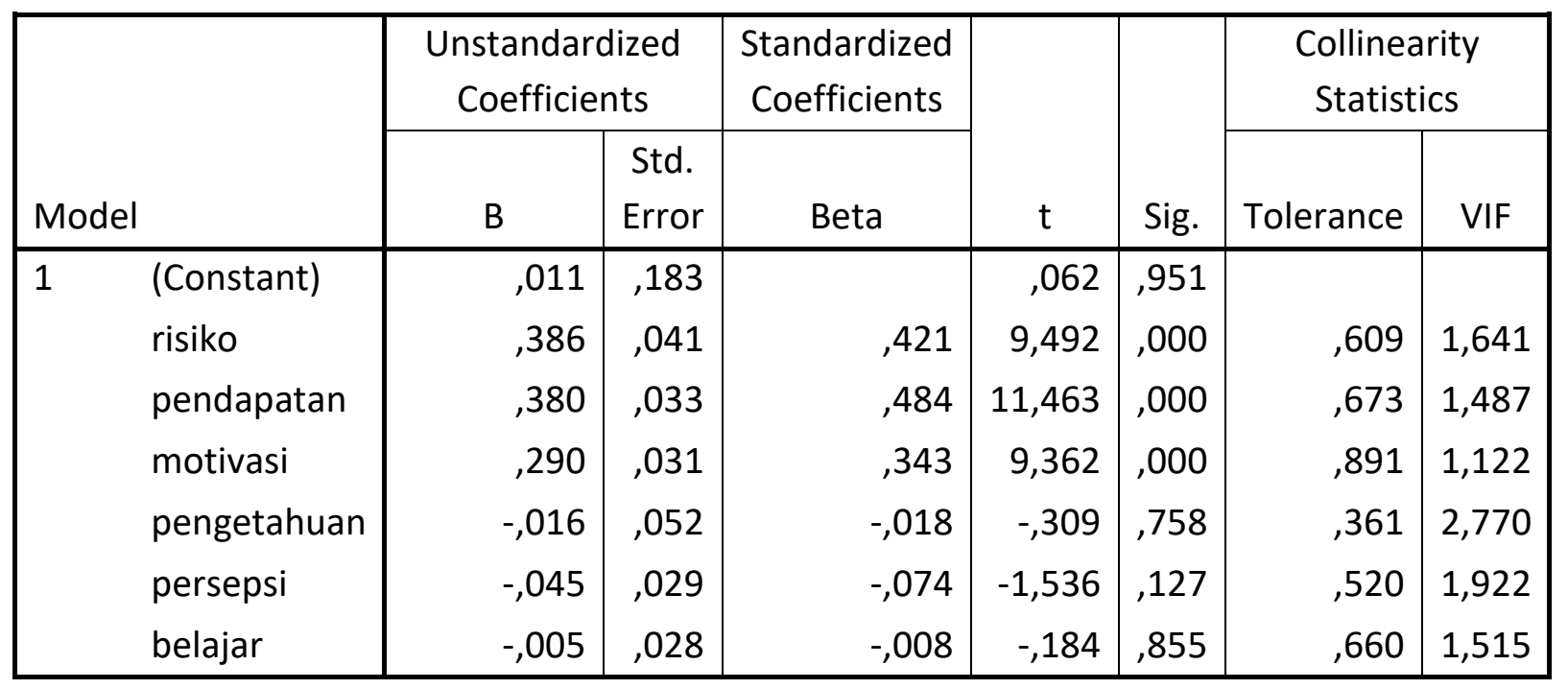

a. Dependent Variable: DV investasi saham syariah

Sumber : Data primer yang diolah

Berdasarkan kolom B pada tabel 4.3 diatas, model regresinya adalah

$Y=0,011+0,386$ X1 +0,380 X2 +0,290 X3-0,016 X4-0,045 X5-0,005 X6

Dimana:

$\mathrm{Y}=$ pertimbangan investasi saham $\mathrm{X} 3=$ Motivasi

syariah di BGIU (Bursa Galeri Investasi $\quad$ X4 = Pengetahuan

UISI) X5 = Persepsi

$\mathrm{X} 1$ = Risiko $\quad \mathrm{X} 6=$ Belajar

$\mathrm{X} 2$ = Pendapatan

\section{SIMPULAN}

Tujuan dari penelitian ini adalah untuk mengetahui pengaruh secara signifikan implementasi belajar, motivasi, pendapatan, persepsi, risiko, dan pengetahuan terhadap pertimbangan investasi saham syariah di BGIU (Bursa Galeri Investasi UISI). Dari hasil pengujian yang dilakukan terhadap 133 responden peserta pelatihan pasar modal tanggal 20 Juni 2016 dan investor yang bertransaksi di BGIU diperoleh hasil sebagai berikut:

Hasil pengujian variabel risiko sesuai model regresi berbanding positif terhadap dependen variabel yaitu minat berinvestasi saham syariah yang mana semakin tinggi risiko semakin banyak atau meningkat peminat investasi disarkan pada indikator pernyataan yang valid yaitu bahwa investor atau responden membeli saham lebih dari satu untuk mengurangi risiko lebih, memilih perusahaan yang liquiditasnya tinggi, saham yang produktif, dan kebijakan yang tepat.

Untuk variabel pendapatan dan motivasi juga berbanding positif terhadap pertimbangan investasi saham syariah. Untuk variabel pendapatan berdasarkan 
indikator pernyataannya bahwa responden akan meningkatkan pembelian saham seiring dengan meningkatnya pendapatan mereka, produktivitas perusahaan meningkat, dan harga saham sesuai dengan pendapatan responden. Sedangkan variabel motivasi, indikator pernyataan dari responden untuk meningkatnya pertimbangan pembelian saham syariah di BGIU adalah dengan harapan untuk mendapatkan keuntungan berinvestasi di saham syariah, keberkahan, terjaminnya pendapatan yang baik, halal, pengembangan keuangan syariah, dan menjadi pemilik perusahaan yang dinvestasikan.

Sedangkan untuk variabel pengetahuan, persepsi, dan belajar adalah berbanding negatif yang mana responden atau investor akan meningkatkan pertimbangan pembelian saham syariah jika indikator dari ketiga variabel tersebut menurun. Dengan kata lain minat investor atau responden untuk pembelajaran, pengetahuan dasar tentang investasi dan persepsi tentang saham syariah kurang begitu diminati atau diperlukan pelatihan. Dari hasil tersebut bisa diketahui bahwa responden sudah mengetahui tentang seluk beluk investasi syariah ataupun tujuan responden lebih kepada aplikasi syariah.

Berdasarkan pada kesimpulan diatas, dapat memberikan saran sebagai berikut:

1. Penelitian lanjutan disarankan menggunakan sampel yang lebih besar dengan periode yang lebih lama untuk memperkuat lagi hasil yang lebih kuat.

2. Penelitian lanjutan dapat menambahkan beberapa variabel untuk memperkuat model yang memerlukan $15 \%$ variabel lain dari model yang sudah terbentuk di penelitian ini

Dari data yang di uji, variabel yang paling signifikan dan positif adalah dari risiko, pendapatan, dan motivasi. Maka untuk sekuritas dapat memberikan pelayanan, pemahaman, fokus, dan konsern lebih pada risiko, produk dan motivasi terhadap responden atau investor yang ada di BGIU, juga peran Bursa Galeri Investasi UISI untuk memasarkan dan memperluas informasi jasa berinvestasi di BGIU agar investor di bursa saham syariah melalui BGIU lebih banyak berdasarkan signifikan variabel positif tersebut.

\section{DAFTAR PUSTAKA}

Alqur'an Al-Karim

Asba, M.Y.A., 2013, Pengaruh Pengetahuan Tentang Efek Syari'ah Terhadap Motivasi Berinvestasi di Pasar Modal Syariah (Studi Kasus di Fakultas Syari'ah dan Ekonomi Islam IAIN Walisongo Semarang), eprints, Walisongo, h.12, 41, dan 48. http://eprints.walisongo.ac.id/1803/3/092411092 Bab2.pdf, diakses pada tanggal 1 Maret 2016.

Bappenas, Kerangka Ekonomi Makro, h.3-1, http://www.bappenas.go.id/files/rkp/rkp2016/Narasi\%20Per\%20Bab/BAB\%203\%20PERPRES\%20RKP\%202016.pdf, diakses pada tanggal 1 Maret 2016. 
Chambali, M., 2010, Analisa Faktor - Faktor Yang Mempengaruhi Minat Masyarakat Berinvestasi Sukuk Melalui Agen Bank Syariah, IAIN Walisongo, Semarang. http://library.walisongo.ac.id/digilib/files/disk1/121/jtptiain-gdl-mochchamba6006-1-skripsi-p.pdf, diakses pada tanggal 1 Maret 2016.

Departemen Keuangan Indonesia, Buku II Nota Keuangan Beserta Rancangan Anggaran Pendapatan Dan Belanja Negara Tahun Anggaran 2016, Jakarta, Indonesia, h.I-4, http://www.anggaran.depkeu.go.id/dja/acontent/NKRAPBN2016.pdf, diakses pada tanggal 1 Maret 2016.

Dewi, A., 2014, Analisis Pengaruh Faktor - Faktor Yang Mempengaruhi Kebijakan Dividen, Suku Bunga Sertifikat Bank Indonesia (SBI) dan Nilai Kurs Terhadap Risiko Investasi di Jakarta Islamic Index (JII) Periode 2005 - 2009. Universitas Lampung (Unila) http://digilib.unila.ac.id/5765/1/BAB\%20l.pdf, diakses pada tanggal 1 Maret 2016.

Halim, 2005, Perbandingan Kinerja Reksadana Saham Konvensional dan Reksadana Syariah, etheses, Universitas Islam Negeri Malang, h.1, http://etheses.uinmalang.ac.id/1540/5/11510032 Bab 1.pdf, diakses pada tanggal 1 Maret 2016.

Irkhami, N., 2010, Analisis Risiko Dalam Investasi Islam, Salatiga, h.9, http://www.muqtasid.iainsalatiga.ac.id/index.php/muqtasid/article/download/1 $\underline{0 / 5}$, diakses pada tanggal 1 Maret 2016.

Komariah, N., 2014, Analisis Perubahan Harga Saham dan Volume Perdagangan Saham Sebelum dan Sesudah Stock Split pada Perusahaan yang Listing di Jakarta Islamic Indeks, IAIN Walisongo, Semarang. http://eprints.walisongo.ac.id/3671/3/102411108 Bab2.pdf, diakses pada tanggal 1 Maret 2016.

Kusmawati, 2011, Pengaruh Motivasi Terhadap Minat Berinvestasi di Pasar Modal Dengan Pemahaman Investasi dan Usia Sebagai Variable Moderat, Jurnal Ekonomi dan Informasi Akuntansi (JENIUS), Vol,.1 No.2 Mei 2011, h.108 http://news.palcomtech.com/wp-content/uploads/2012/01/KUSMAWATIJE01022011.pdf, diakses pada tanggal 1 Maret 2016.

Makaryanawati, 2016, Pengaruh Tingkat Suku Bunga dan Tingkat Likuiditas Perusahaan Terhadap Risiko Investasi Saham Yang Terdaftar Pada Jakarta Islamic Index, Malang, h.50, http://fe.um.ac.id/wpcontent/uploads/2010/01/makaryanawati 7.pdf, diakses pada tanggal 1 Maret 2016.

Mansur, D.P, et al, 2016, Minat Berinvestasi di Pasar Modal Syariah: Aplikasi Theory of Planned Behaviour Serta Implikasinya Terhadap Strategi Targetting Program Promosi Pasar Modal Syariah di Kalangan Mahasiswa. Fakultas Ekonomi Universitas

Indonesia, 
Malik | Jurnal Ekonomi dan Bisnis Islam, Vol. 3, No. 1, Januari-Juni 2017

https://www.academia.edu/9586780/Minat Berinvestasi Di Pasar Modal Syari ah Aplikasi Theory Of Planned Behaviour Serta Implikasinya Terhadap Strat egi_Targetting_Program_Promosi_Pasar_Modal_Syariah_di_Kalangan_Mahasisw a, diakses pada tanggal 1 Maret 2016.

Muhsinhar, 2011, Telaah Kritis Pasar Modal Syariah, Universitas Muhammadiyah Yogyakarta, http://muhsinhar.staff.umy.ac.id/telaah-kritis-pasar-modal-syariah/, diakses pada tanggal 1 Maret 2016.

Mustofa, 2015, Preferensi Dosen IAIN Sultan Amai Gorontalo Terhadap Perbankan Syariah di Gorontalo, Al-Buhuts, IAIN Sultan Amai Gorontalo, h.33, https://www.google.co.id/url?sa=t\&rct=j\&q=\&esrc=s\&source=web\&cd=55\&cad= rja\&uact=8\&ved=0ahUKEwi4oaOxoL LAhXDkZQKHYXxCZg4MhAWCC4wBA\&url=h ttp\%3A\%2F\%2Fwww.journal.iaingorontalo.ac.id\%2Findex.php\%2Fab\%2Farticle\% 2Fview\%2F325\%2F243\&usg=AFQjCNGWnTRQgKovgdeJWp4 A4Mkh4cx3Q\&sig2= OWOPMG2e0-QkWE4N8V1ncA\&bvm=bv.116573086,bs.1,d.dGY, diakses pada tanggal 1 Maret 2016.

Muttaqien, D., 2009, Aspek Legal Lembaga Keuangan Syari'ah, Safitri Insania Perss, Yogyakarta, op.cit, h.51, http://eprints.walisongo.ac.id/1803/3/092411092 Bab2.pdf, diakses pada tanggal 1 Maret 2016.

OJK, 2015, Statistika Saham Syariah November 2015, Jakarta, http://www.ojk.go.id/id/kanal/syariah/data-dan-statistik/sahamsyariah/Documents/Pages/Statistik-Saham-Syariah-November2015/Statistik\%20Saham-November.pdf, diakses pada tanggal 1 Maret 2016.

OJK, 2016, Pasar Modal Syariah, Jakarta, http://www.ojk.go.id/id/kanal/syariah/tentangsyariah/pages/pasar-modal-syariah.aspx, diakses pada tanggal 1 Maret 2016.

Pratama, D.I., 2013, Investasi, Universitas Lampung (Unila), h.18, http://digilib.unila.ac.id/978/8/BAB\%20Il.pdf, diakses pada tanggal 1 Maret 2016. Bungin, B, 2008, Metodologi Penelitian Kuantitatif, Komunikasi, Ekonomi, dan Kebijakan Publik, Serta Ilmu - ilmu Sosial lainnya, Jakarta h.25 di Silmy, F.I., 2011, Faktor Faktor Yang Mempengaruhi Pertimbangan Investasi Saham Syariah, Jakarta. h.50, http://repository.uinjkt.ac.id/dspace/bitstream/123456789/4748/1/FIKRI\%20IND RA\%20SILMY-FSH.pdf, diakses pada tanggal 1 Maret 2016.

Salim, H.S dan Sutrisno, B., 2008, Hukum Investasi di Indonesia, op.cit, PT Rajagrafindo Persada, Jakarta, h.37, http://eprints.walisongo.ac.id/1803/3/092411092 Bab2.pdf, diakses pada tanggal 1 Maret 2016.

Sarah, A.P, 2014, Faktor Yang Mempengaruhi Minat Investor Terhadap Sukuk Negara Ritel, Jurnal Ekonomi Islam Republika, Iqtishodia, Institut Pertanian Bogor, 
http://fem.ipb.ac.id/d/iqtishodia/2014/Iqtishodia 20141023.pdf, diakses pada tanggal 1 Maret 2016.

Sari, D.L., 2008, Aplikasi Model Multinominal Logit Untuk Mengetahui Faktor - Faktor Yang Mempengaruhi Minat Investor Individu Terhadap Reksa Dana Syariah, Universitas Indonesia, http://lib.ui.ac.id/file?file=digital/117593-T\%2025032Aplikasi\%20model-abstrak.pdf, diakses pada tanggal 1 Maret 2016.

Siahaan, N.M, 2011, Keuntungan Melakukan Investasi Dalam Surat Berharga, Universitas Sumatera Utara (USU), http://repository.usu.ac.id/bitstream/123456789/29810/3/Chapter\%20ll.pdf, diakses pada tanggal 1 Maret 2016.

Silmy, F.I., 2011, Faktor - Faktor Yang Mempengaruhi Pertimbangan Investasi Saham Syariah, UIN Syarif Hidayatullah, Jakarta, http://repository.uinjkt.ac.id/dspace/bitstream/123456789/4748/1/FIKRI\%20IND RA\%20SILMY-FSH.pdf, diakses pada tanggal 1 Maret 2016.

Suliyanto, 2010, Loc.Cit, h.82-82, di Chambali, M, Analisa Faktor - Faktor Yang Mempengaruhi Minat Masyarakat Berinvestasi Sukuk Melalui Agen Bank Syariah, IAIN Walisongo, Semarang, h.55, http://library.walisongo.ac.id/digilib/files/disk1/121/itptiain-gdl-mochchamba6006-1-skripsi-p.pdf, diakses pada tanggal 1 Maret 2016.

Wahyuni, E.S., 2015, Analisa Faktor - Faktor Yang Mempengaruhi Harga dan Perkembangan Saham Syari'ah di Indonesia. IAIN Bengkulu, https://www.google.co.id/url?sa=t\&rct=i\&q=\&esrc=s\&source=web\&cd=26\&cad= ria\&uact $=8 \&$ ved $=0$ ahUKEwiAmcumr LAhWDX5QKHVwLAZw4FBAWCDgwBQ\&url=http\%3A\%2F\%2Fjurnal.unived. ac.id\%2Findex.php\%2Fer\%2Farticle\%2Fdownload\%2F147\%2F139\&usg=AFQjCNH TgOc7TvUzbwVa4L59uqH4TT6g\&sig2=RhJFCMg3gqbWFuNcD6mLMw\&bvm=bv .116573086, bs.1,d.dGY, diakses pada tanggal 1 Maret 2016. 